Canadian University Music Review

Revue de musique des universités canadiennes

\title{
Robin Elliott. Counterpoint to a City: The First One Hundred \\ Years of the Women's Musical Club of Toronto. Toronto: ECW \\ Press, 1997. 249 pp. ISBN 1-55022-306-2 (paperback)
}

\section{Glenn Colton}

Volume 20, numéro 1, 1999

URI : https://id.erudit.org/iderudit/1015649ar

DOI : https://doi.org/10.7202/1015649ar

Aller au sommaire du numéro

Éditeur(s)

Canadian University Music Society / Société de musique des universités canadiennes

\section{ISSN}

0710-0353 (imprimé)

2291-2436 (numérique)

Découvrir la revue

Citer ce compte rendu

Colton, G. (1999). Compte rendu de [Robin Elliott. Counterpoint to a City: The First One Hundred Years of the Women's Musical Club of Toronto. Toronto: ECW Press, 1997. 249 pp. ISBN 1-55022-306-2 (paperback)]. Canadian University Music Review / Revue de musique des universités canadiennes, 20(1), 101-104. https://doi.org/10.7202/1015649ar

All Rights Reserved @ Canadian University Music Society / Société de musique des universités canadiennes, 2000
Ce document est protégé par la loi sur le droit d'auteur. L'utilisation des services d'Érudit (y compris la reproduction) est assujettie à sa politique d'utilisation que vous pouvez consulter en ligne.

https://apropos.erudit.org/fr/usagers/politique-dutilisation/ 


\section{BOOK REVIEWS / COMPTES RENDUS}

Robin Elliott. Counterpoint to a City: The First One Hundred Years of the Women's Musical Club of Toronto. Toronto: ECW Press, 1997. 249 pp. ISBN 1-55022-306-2 (paperback).

Since the late nineteenth century, women's musical clubs have played an integral role in the musical life of Canada. With the establishment of the first such club in Hamilton in 1889 and the founding of similar minded organizations in the cities of Québec City, Montréal, Ottawa, Winnipeg, and Toronto shortly thereafter, ${ }^{1}$ the seeds of the women's musical club movement were firmly planted in this country, many of which have yielded vibrant, flourishing groups which continue their activities to the present day.

Robin Elliott provides a fresh account of the evolution of one these organizations in this recently published book from ECW Press. Counterpoint to a City: The First One Hundred Years of the Women's Musical Club of Toronto is precisely what the title implies-a history of the club from its inception in 1899 to the present day. The author draws upon existing sources-including archival materials, reviews, and, most notably, Helen Goudge's 1972 history of the club-to compile an up-to-date and informative narrative.

The first two chapters establish the historical context in which the WMC came into being. The author provides an excellent overview of the cultural climate of late nineteenth-century Toronto and a perceptive (albeit brief) assessment of professional opportunities for women in music at the turn of the century, followed by the story of how the club was founded.

Here, as elsewhere in the book, the reader may wish for further elaboration on certain points. Elliott's discussion of late nineteenth- and early twentiethcentury Canadian women musicians, for example, seems incomplete and far too brief. Emma Albani is mentioned along with several others, yet on the subject of Canadian women pianists Elliott tells us only that "none enjoyed an international career on the level of Albani...," yet "many appeared within Canada and abroad as soloists" (p. 22). None of these women are named, nor is there any explanation proposed as to why Canadian women pianists did not attain the same international stature as Albani and others.

The remaining chapters focus primarily on the organization's concert activities from 1899 to the present day. As Elliott rightly points out in the preface to the book, "the main business of the WMC has been and continues to be the

1 Many other Canadian centres followed suit in the years which followed, with clubs founded in Calgary, Halifax, Vancouver, Victoria, Regina, Edmonton, Saskatoon, and Lethbridge in the early decades of the twentieth century (Encyclopaedia of Music in Canada, 2nd ed., s.v. "Women's Musical Clubs"). 
sponsoring of concerts" (p. 11), and this is reflected in the author's exhaustive treatment of this area.

The third chapter gives an excellent overview of the club's first decade, documenting concert activities and administrative matters, but also delving deeper into the social significance of the organization for Canadian women musicians at the turn of the century: "One of the many benefits of the WMC concerts was the opportunity provided for these women to continue to perform before an audience under socially approved conditions" (p. 50). Chapter 4 documents the development of the club in the early decades of the twentieth century and offers some perceptive observations on the state of musical affairs in Toronto. Elliott notes, for example, that the activities of musical clubs in Toronto were being reported upon in contemporary publications with increasing frequency and that the number of clubs had reached unprecedented heights during this period.

One criticism which applies here as well as in subsequent chapters is the author's vague usage of certain words and phrases, most notably a recurring tendency to describe certain composers or works as "tame." For example, "The WMC choir sang two works for chorus and orchestra by U.S. composers: $A$ Legend of Granada by Henry Hadley (1871-1937), and Song of Sunrise by Charles Fonteyn Manney (1872-1951). This was tame fare by comparison with the orchestral numbers, but nevertheless there was a positive review in the Mail and Empire" (p. 74). ${ }^{2}$ From this we are led to believe that "tame fare" is not altogether a good thing, yet the precise meaning remains unclear. By "tame" does Elliott mean music which is (1) of inferior quality, (2) easy to perform, (3) easily accessible for a general audience, or (4) some, all, or none of the above?

Chapters 5 through 7 discuss what was arguably the most turbulent period in the WMC's history, the years from the end of the First World War to the aftermath of World War II. As Elliott's meticulously detailed commentary illustrates, there were a number of crises during these years which, at times during the 1920s, threatened the very existence of the organization. Declines in attendance and membership are cited as two of the chief problems, yet the club still managed to showcase some impressive talent in its concert series, including the Canadian debut of Wanda Landowska, a concert of music by Healey Willan (with the composer accompanying violinist Harry Adaskin and soprano Jeanne Dusseau), and an appearance by Ernest MacMillan, in performance with the Academy String Quartet.

It is a testament to the determination and commitment of these women that the WMC not only emerged intact after the internal struggles of the 1920s, but actually grew and prospered amidst the dire economic conditions of the 1930s and continued to survive throughout the Second World War. As Elliott notes, the onset of war affected the activities of the club in several ways: the number of concerts was reduced (as was the membership fee) and contracts with

2 The "orchestral numbers" included Berlioz's Benvenuto Cellini Overture, Liszt's Les préludes, Strauss's Don Juan, and Wagner's Rienzi Overture (pp. 73-74). 
musicians in enemy countries were cancelled, necessitating a search for affordable replacement artists.

In the next three chapters, Elliott tells the story of the organization's growth and development from the late 1940s to the late 1970s and its increasingly high profile as a concert giving body and discoverer of new talent. Among the more noteworthy WMC activities during these decades were the awarding of the organization's first scholarship in 1950 (a practice which has continued to the present day), the club's integral role in the creation of the Hart House Orchestra in 1954, and the continued sponsorship of concerts featuring both established and rising stars from Canada and abroad.

The author's coverage of these and other topics is informative and meticulously thorough, as is his discussion of the administrative activities of the club, biographical sketches of prominent club members, and the topic of primary emphasis throughout the book, the WMC's concert activities (complete with detailed commentary on visiting artists, quotes, and samples of reviews from Toronto critics).

One of the more interesting sections is Elliott's brief, yet perceptive assessment of the club's internal debate over the merits of modern music in the early 1960 s, following a period of arch-conservatism in which new works were seldom heard at WMC-sponsored concerts. Also intriguing is Elliott's reference to a somewhat unusual membership drive apparently motivated by a desire to increase the perceived social status in becoming a WMC member and, at the same time, mirror the practices of the Montréal club: "A concerted campaign now began in earnest to raise the number (of members) to 1000 , at which point the plan was to close the membership and start a waiting list, just as the Ladies' Morning Musical Club of Montréal had done" (p. 167).

One of the principal drawbacks of the book, perhaps unavoidable given the scope of the subject, is that a host of fascinating issues raised during the course of discussion are rarely addressed in sufficient depth. In Chapter 8, for example, Elliott offers an excellent summary of the Toronto debut of Maureen Forrester in a WMC concert and even cites a passage from the singer's memoirs on the decline of the women's musical club movement. Even more useful, however, would be further elaboration on Forrester's relationship to the WMC, the role of the organization in her career, and an expanded discussion on her beliefs about the women's musical club movement. Similar attention could be given to other Canadian musicians associated with the WMC. How has the WMC affected their lives and to what extent, if any, has the success of their musical careers been intertwined with the emergence of the WMC as a supporter of young talent?

Chapters 11 and 12 complete the recent history of the club up to the publication of the present volume. As was the case in previous chapters, Elliott gives a meticulously detailed account of the club's concert activities and administrative operations during the past twenty years, a period in which the organization moved from its traditional concert venue-Eaton Auditoriumand ultimately relocated to the University of Toronto's Walter Hall. A brief closing chapter offers some insightful reflections on the social and cultural 
significance of the WMC and an overview of the women's musical club movement in North America.

While I may have wished for more emphasis on the "living history" of the WMC (i.e., less reliance on archival and printed materials and more first hand interviews with living performers and WMC members), Elliott has succeeded admirably in compiling a well-written and exceptionally thorough narrative of the club's first century of activities. The minute attention to details of individual performances and administrative matters, while of limited appeal to a general readership, makes the book a valuable reference tool for researchers with an interest in women's musical clubs in general and the Women's Musical Club of Toronto specifically. As the author points out in his closing chapter, "the study of the women's musical club movement is still in its infancy, despite the fact that thousands of such organizations have flourished in centres large and small throughout North America during the past 125 years" (p. 221). Elliott's book may well pave the way for future research into the accomplishments of these remarkable women.

Glenn Colton

Diane E. Peters. Canadian Music and Music Education: An Annotated Bibliography of Theses and Dissertations. Lanham, Md.: The Scarecrow Press, 1997. xvii, 476 pp. ISBN 0-8108-3275-5 (hardcover).

The field of Canadian music research has come a long way in recent decades. With courses in Canadian music now firmly established as an integral part of the curriculum in many of our music departments and a plethora of recently completed publications, dissertations, and theses on aspects of music in Canada, books such as Diane Peters's annotated bibliography of theses and dissertations on Canadian music and music education are welcome additions to this rapidly growing field. ${ }^{1}$

As Peters rightly points out in the introduction to the book, existing dissertation abstracts are of limited value when searching for current scholarship on Canadian music, and Master's level works completed at American or foreign universities are often extremely difficult to uncover.

The present volume includes annotated bibliographic citations of over 1,200 theses and dissertations relating to aspects of Canadian music or music education in Canada. The scope of the entries is impressive, with the bibliography partitioned neatly into 15 sections as follows: (1) Analytical Studies: General; (2) Analytical Studies: Instrumental Music; (3) Analytical Studies: Vocal Music; (4) Bibliographies/Inventories/Repertoire Lists; (5) Ethnomusicology/Folk Music; (6) Historical/Bibliographical Studies; (7) Music and Literature; (8) Music Education; (9) Music Journalism/Criticism; (10) Music Recording/Broadcasting;

1 Mention must also be made here of Carl Morey's informative annotated bibliography, Music in Canada: A Research and Information Guide (New York and London: Garland, 1997). Morey's book, while more selective than the present volume by Peters, includes both published and unpublished sources. 